UDC 621.165:532.6

P. KLONOWICZ, PhD., Research Associate at IFFM PAS, Gdansk;

R. $\boldsymbol{R} \boldsymbol{U} \boldsymbol{S} \boldsymbol{A} \boldsymbol{N} \boldsymbol{O} \boldsymbol{V}$, M.Eng., Research Assistant at IFFM PAS, Gdansk;

A. RUSANOV, D.Sc., Prof., Deputy Director for Science at IPMach NASU, Kharkov;

P. LAMPART, D.Sc., Assoc. Prof., Head of the Centre of Heat and Power

Engineering at IFFM PAS, Gdansk;

T. K. SUCHOCKI, M.Eng., Research Assistant at IFFM PAS, Gdansk;

J. SURWILO, M.Eng., Research Assistant at IFFM PAS, Gdansk

\title{
METHODS FOR DESIGN OF RADIAL-AXIAL TURBINES FOR ORC COGENERATION UNIT WORKING WITH MDM
}

The paper describes two methods of design of blading systems of radial-axial turbines for an Organic Rankine Cycle (ORC) cogeneration unit working with silica oil MDM. Preliminary design of the turbine flow part draws on methods of 1D calculation and pre-selection of basic geometric characteristics. Final design involves also methods for construction of 3D geometry and methods of 3D flow calculations of the turbine flow part. 3D numerical calculations of turbine flows are made with the help of the software package IPMFlow, developed based on the earlier codes FlowER and FlowER-U, or using the software complex ANSYS. $100 \mathrm{~kW}$ ORC turbine designs with the single-stage radial-axial turbine are elaborated in this paper.

Key words: cogeneration unit, Organic Ranking Cycle, CFD, radial-axial turbine

\section{Introduction}

A promising direction in the development of energy saving technologies is the use of low-power cogeneration plants working on low-boiling working fluids. Such plants can be used for disposal of low-temperature thermal waste and for work on renewable fuels such as different types of biomass.

An important element of the ORC cogeneration plant is turbine. The peculiarity of low-power ORC turbines, that is its relatively small size, makes a non-trivial task to achieve an acceptable level of gas-dynamic perfection.

Centripetal turbines are widely used whenever a compact design is required, for example in turbocompressors. This type of stage is characterized by a relatively high efficiency and can process relatively large enthalpy drops. A highly loaded stage, especially for large particle fluids like MDM, can process pressure ratios over 100 and according to some authors even up to 400 [1]. For this reason they are attractive from the point of view of microcogeneration, when an ORC system is used [2].

The paper describes two methods of turbine design, the first method was developed at the Szewalski Institute of Fluid-Flow Machinery, Polish Academy of Sciences (IFFM PAS) in Gdansk, the second - at the A.N. Podgorny Institute for Mechanical Engineering Problems of National Academy of Sciences of Ukraine (IPMach NASU) in Kharkov. In the first method the software package $A N S Y S$ is used for the numerical investigation of viscous flow in turbines A 3D turbulent flow model for the second method is realised in the program complex IPMFlow, which originates from the programs FlowER and FlowER-U. Also, examples of designs of flow parts of the radial-axial type turbines using these methods are presented. 
An algorithm for the designing of turbine flow parts developed at IFFM PAS

The design process begins with 1D meanline calculations. The design data can consist of non-dimensional parameters such as velocity ratio, blade load coefficient, flow coefficient, specific speed or diameter etc. or alternatively, whenever specific constraints are imposed on the dimensions the parameters, of the dimensional parameters such as diameters or blade heights. The losses can be approximated by various correlations such as Traupel [3] or Abramov-Filipov-Frolov [4]. It can be assumed that the impeller is unshrouded or shrouded. The shrouded variant is usually preferable as it not only allows us to obtain a greater efficiency of the flow system, but in addition reduces the axial force acting on the shaft, because the cover acts as a partial relief. Fig. 1 shows how the isentropic efficiency of the turbine changes depending on the size of tip clearance. It can be observed that this solution gives efficiency benefits in the range of 3 to 5 percent for practical values of tip clearance. The disadvantages of the shrouding include more difficult technology and worsened structural properties. Nevertheless, the peripheral speeds in organic fluids are relatively small.

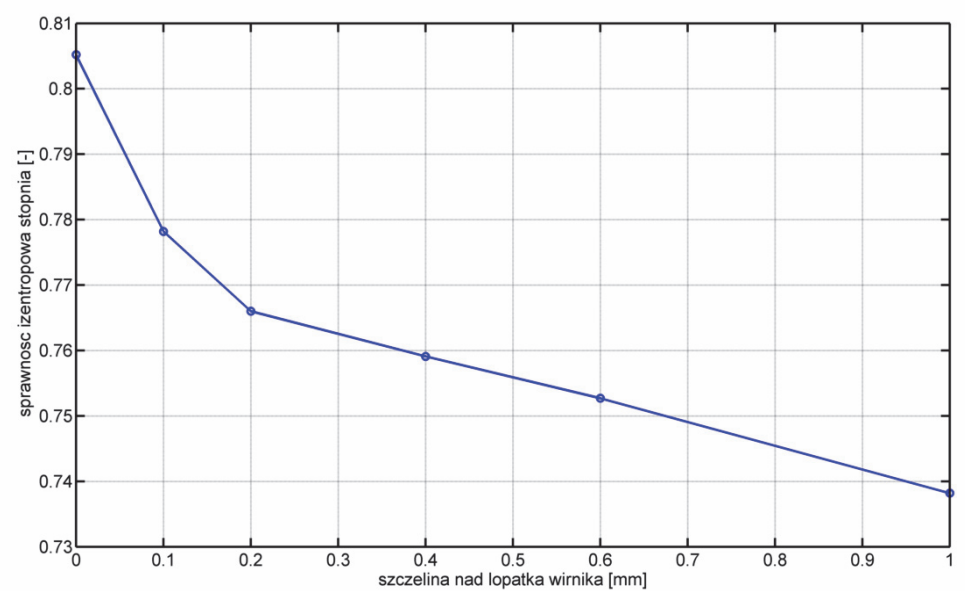

Fig. 1 - Internal efficiency of an exemplary centripetal stage with respect to the tip clearance size

Due to the high values of the Mach number at the nozzle outlet it is necessary to use de Laval nozzle. One of the methods of designing shape of the divergent part is the method of characteristics. This is to avoid the shock wave in the divergent part of the channel. The method of characteristics is used to solve the potential flow equation in supersonic regime $[5,6]$

$$
\left(u^{2}-a^{2}\right) u_{x}+\left(v^{2}-a^{2}\right) u_{y}+2 u v u_{y}-\frac{\delta a^{2} v}{y}=0
$$

with the assumption that the flow is irrotational

$$
u_{y}-u_{x}=0
$$

The thermodynamic closure can be defined as

$$
\begin{gathered}
V^{2}=u^{2}+v^{2} ; \\
a=a(V) .
\end{gathered}
$$

The initial transonic line can be obtained from the Sauer [7] scheme

$$
2 \Gamma u u_{x}-v_{y}=0 \text {, }
$$

where $\Gamma$ is the fundamental constant for gas dynamics

$$
\Gamma=1+\frac{\rho}{a}\left(\frac{\vartheta a}{\vartheta p}\right)_{S} .
$$


An example of a nozzle shape can be seen in Figure 2.

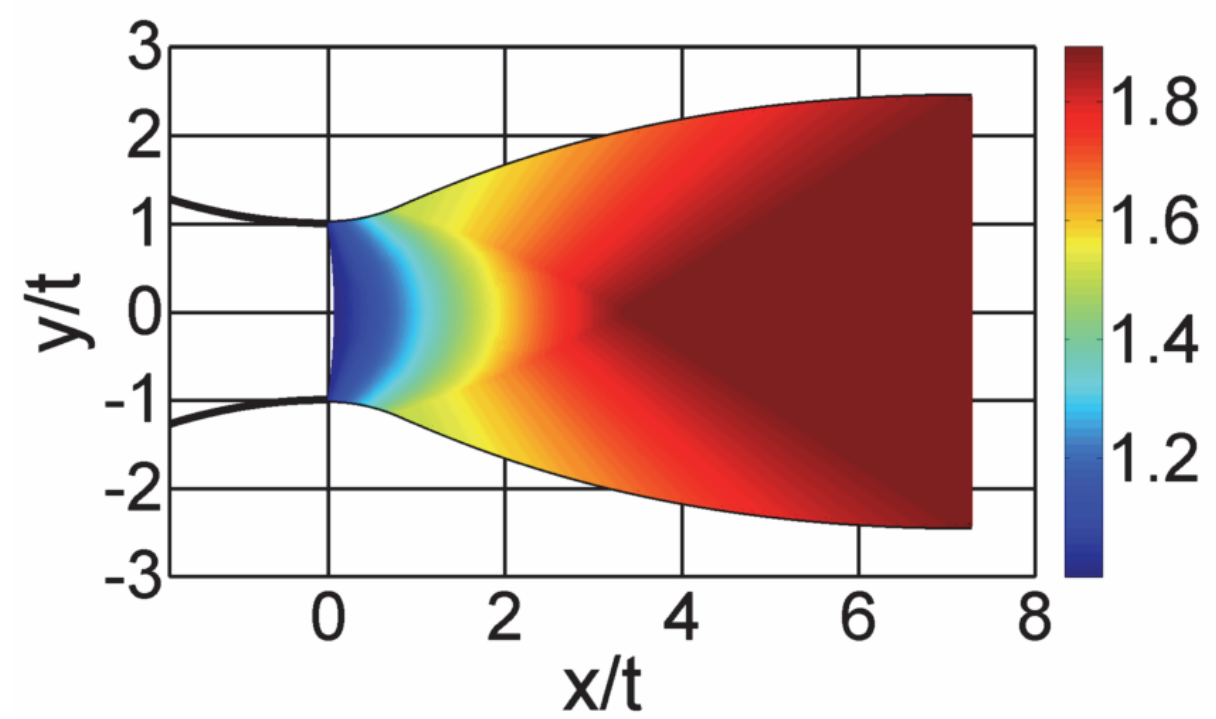

Fig. 2 - The distribution of Mach number in the convergent-divergent nozzle

When the nozzle shape is obtained, the blade shape can be constructed, Figure 3 . The de Laval nozzle can be symmetric or asymmetric.

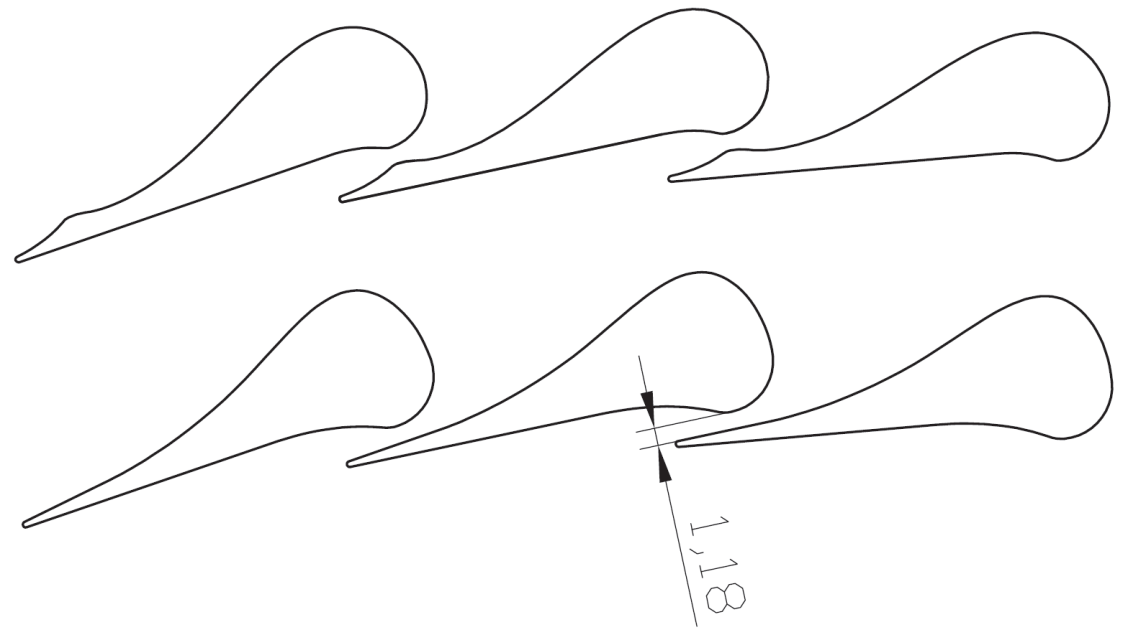

Fig. 3 - Examples of nozzle blades, top - symmetric, bottom - asymmetric

The rotor blade is designed in the BladeGen software, which is a part of the ANSYS software [8]. The whole passage is defined by hub and shroud curves, which can be built of splines or Bezier curves. The blade shape is defined as the distribution of the backbone line angle from inlet to outlet and its thickness. The distributions can again be made of splines or Bezier curves of any order. An example of a complete radial-axial stage is presented in Figure 4. Once the geometry is created, the stage can be analysed by means of three dimensional CFD. The domain discretisation is performed in ANSYS TurboGrid or ICEM $C F D$ packages [8].

The designed radial-axial turbine is a $200 \mathrm{~kW}$ machine operating on MDM as a working medium. The inlet parameters are determined here as: pressure -12 bar, temperature $553.5 \mathrm{~K}$. For the cogeneration ORC installation, the temperature in the condenser was set at $363 \mathrm{~K}$ at the saturation pressure of 0.17 bar. The ORC cycle is equipped with a recuperator to 
increase the cycle efficiency. The resulting pressure drop in the turbine blading system is equal to 70 . The rotational speed of the rotor was assumed equal to $15000 \mathrm{rev} / \mathrm{min}$.

Sample stator and rotor meshes used in the process of 3D computations of this ORC turbine are illustrated in Figures 5 and 6. Mach number contours at the mid-span section of the nozzles is presented in Figure 7. An example of pressure distribution in the rotor is shown in Figure 8. The turbine stages designed through the described methodology can easily achieve efficiencies approaching $90 \%$ despite of the fact that the stages are highly loaded and flow can have high Mach numbers.

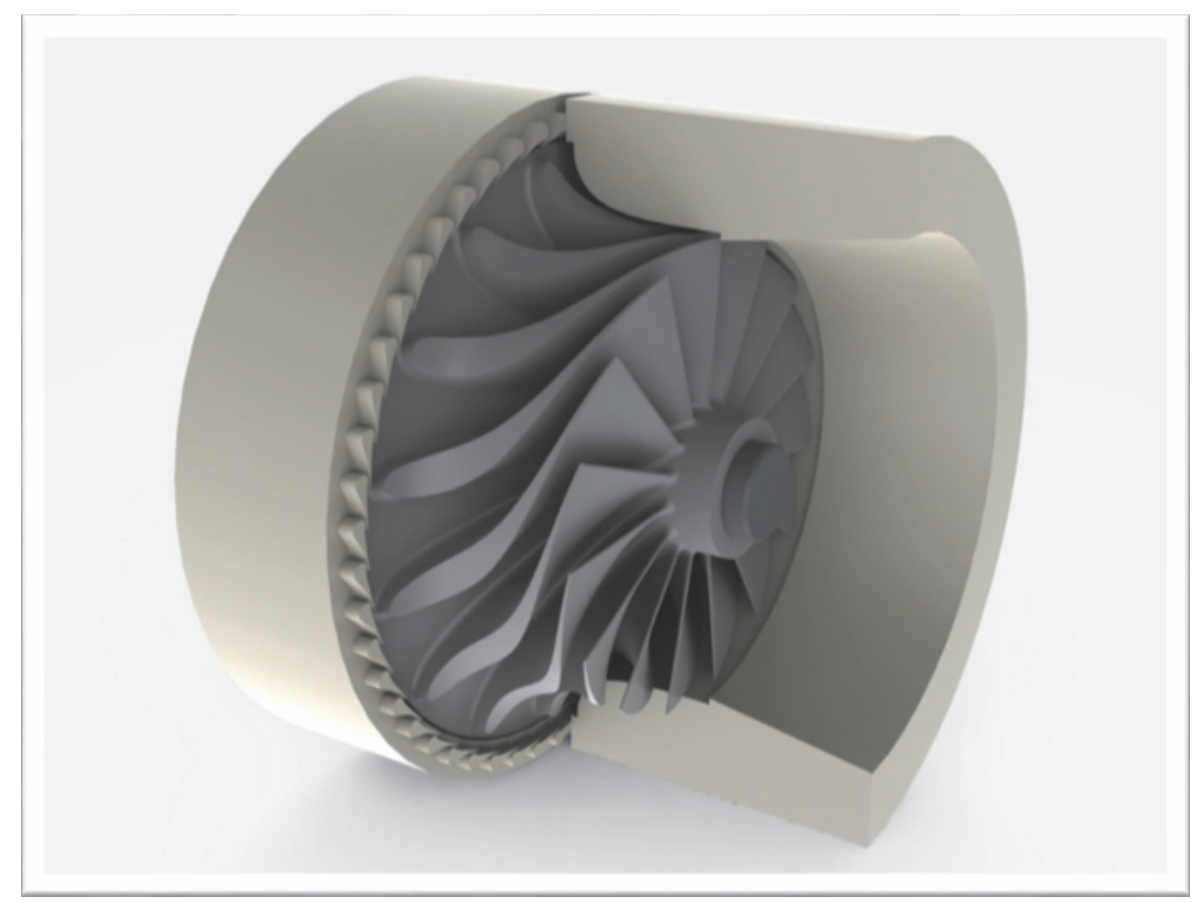

Fig. 4 - A model of the stator-rotor radial-axial turbine stage

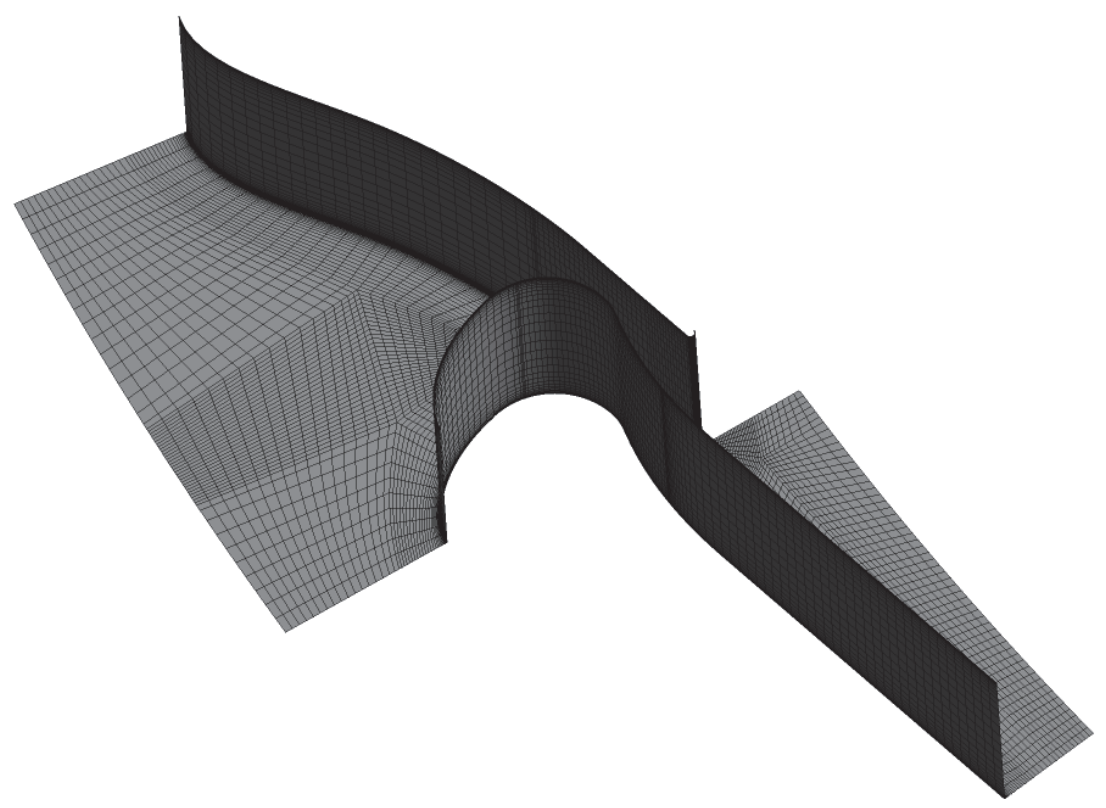

Fig. 5 - Example of a stator mesh 


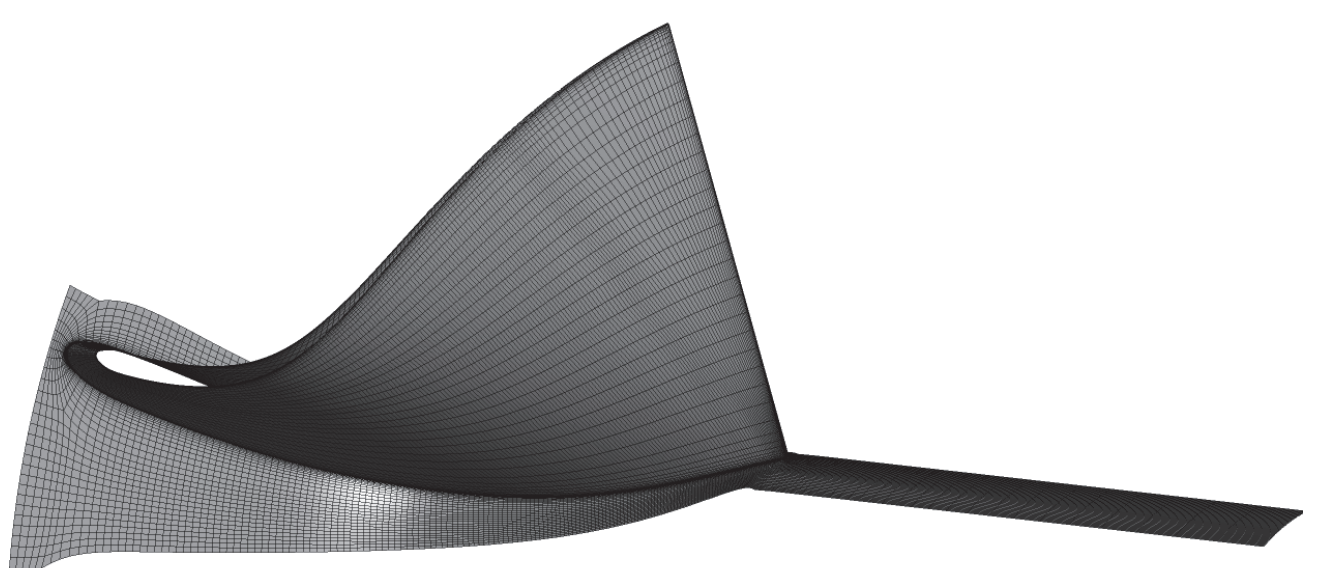

Fig. 6 - Example of a rotor mesh

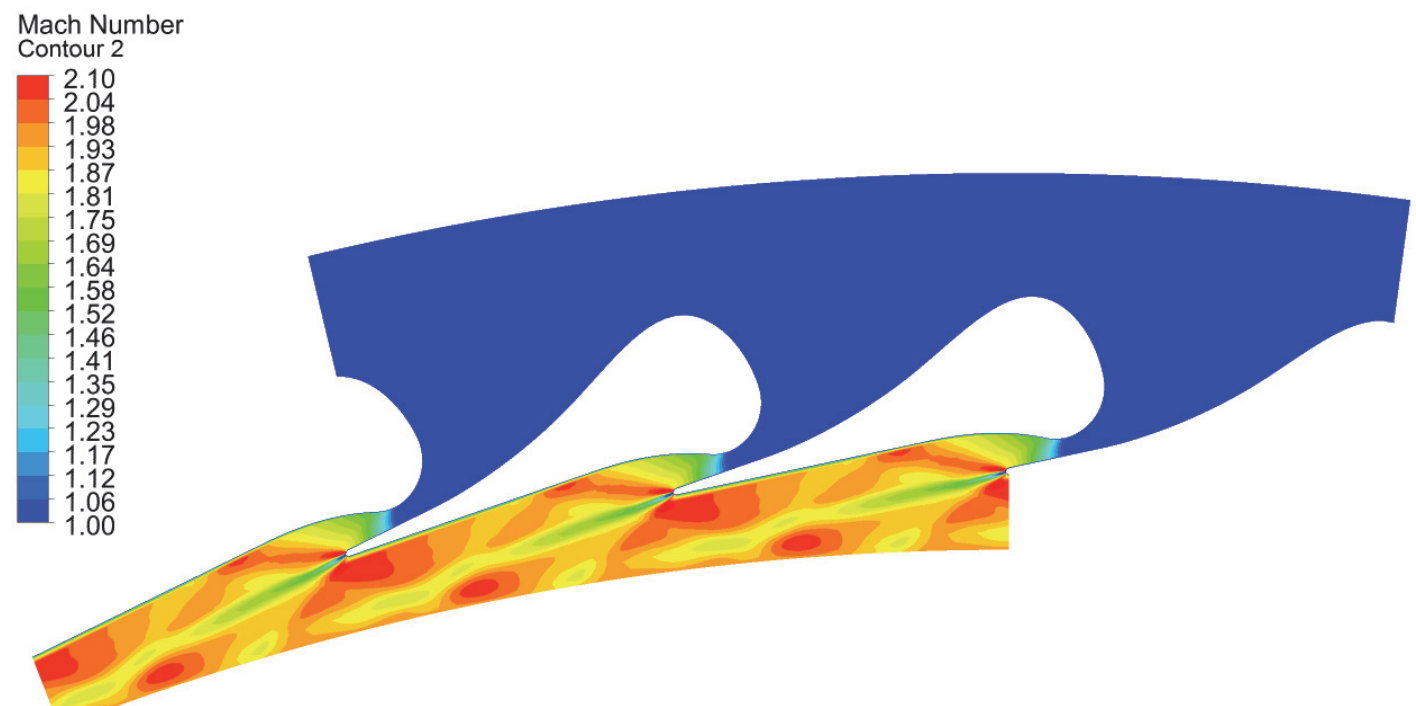

Fig. 7 - The distribution of Mach number in the nozzle at the mid-span
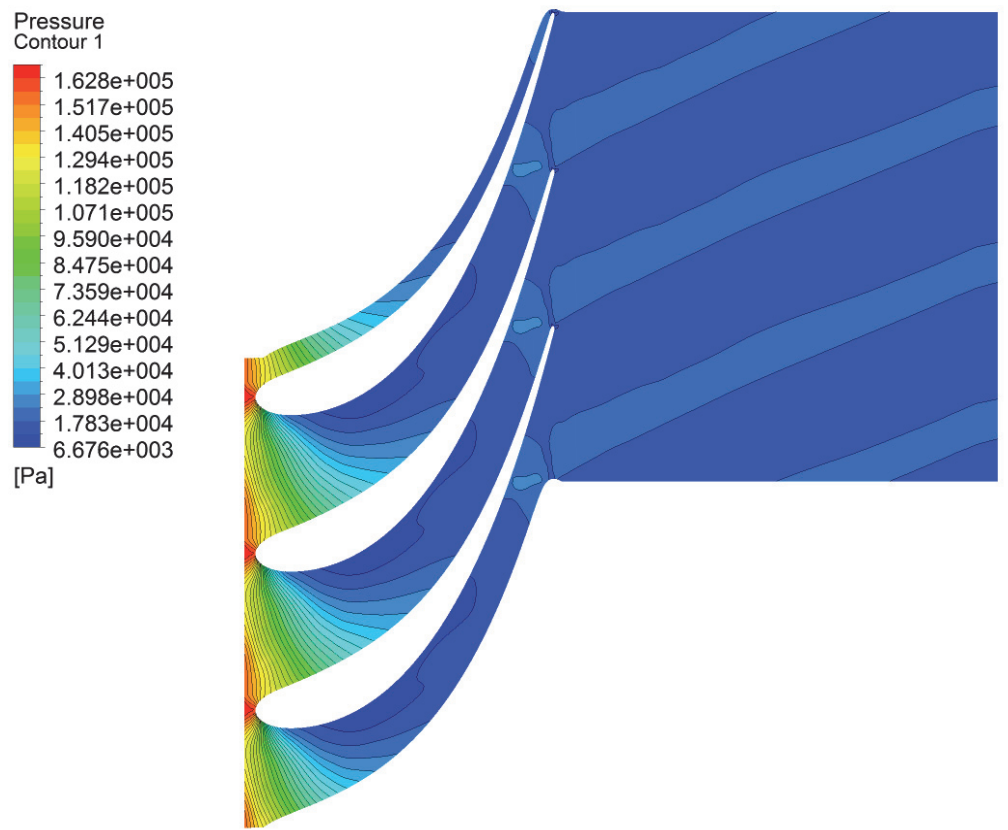

Fig. 8 - The pressure distribution in the rotor at the mid-span 


\section{A method for the designing of turbine flow parts at IPMach NASU}

An algorithm for the designing of turbine axial and radial-axial types is introduced in Figure 9. The first step is a preliminary calculation of geometrical characteristics of the flow part using relatively simple methods, based on solving one-dimensional or quasi-axialsymmetric equations $[9,10]$.

To construct the full three-dimensional geometry of the flow part on the basis of the obtained geometric characteristics, analytical methods of profiling of flow parts are used. These methods allow us to build turbine stages of axial and radial-axial types.

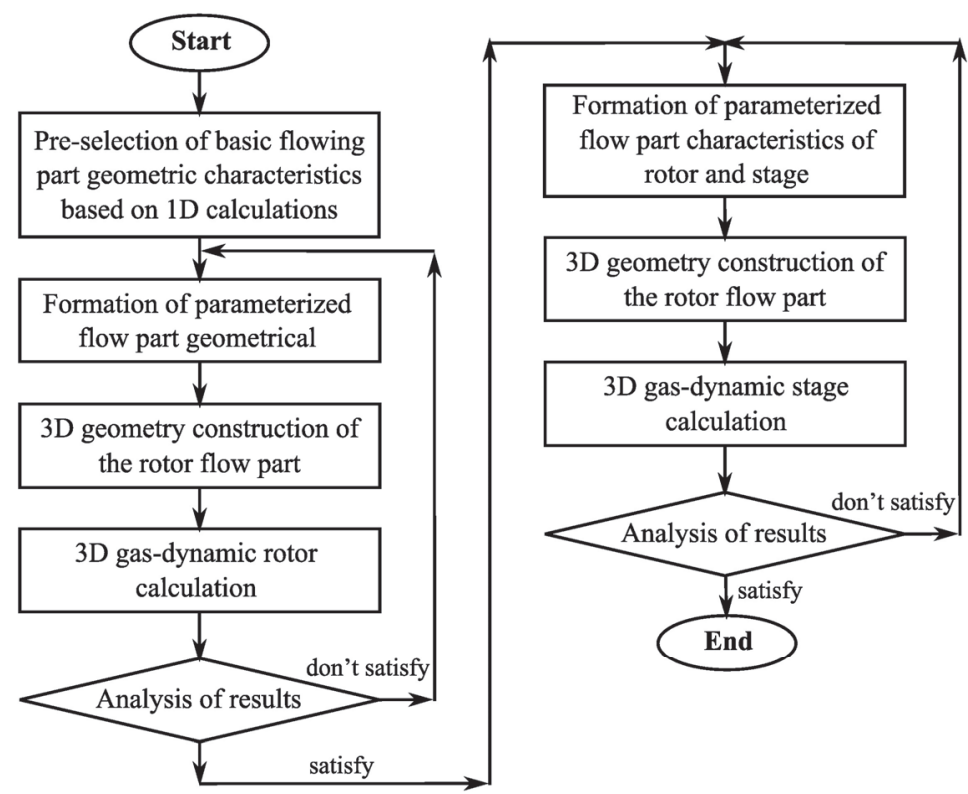

Fig. 9 - Flowchart of flow part stage designing

Calculations of three-dimensional turbine flows are performed using the program complex IPMFlow. Most of 3D calculations are performed on coarse grids (with a relatively small number of cells). The refined grids are used only for final calibration calculations. The algorithm of designing the flow part is automated. Several methods for solving optimization tasks such as the Nelder-Mead method and genetic algorithms are used to generate new values of variable parameters (geometric characteristics of the flow part). An automated approach usually requires several hundreds of iterations $[9,11]$. Stochastic methods allow for searching of global extremes, but this usually involves increased computational costs $[12,13]$. In the given examples, it took up to one hundred 3D calculations to obtain the final form of one stage.

\section{Building of 3D geometry of the flow part}

For building the radial-axial turbine stage, a method described in [14] is used (Fig. 10). The leading edge is assumed parallel to the rotational axis $x$, the trailing edge is normal.

Tip and hub endwalls are described by curves consisting of an arc and a straight connected with the arc. Initial data for the construction of meridional endwalls are: $r_{\max }, r_{\min }-$ maximum and minimum radiuses of the rotor channel; $x_{\max }$ rotor width; $l_{i n}, l_{e x}-$ inlet and exit heights; $\alpha_{i n}^{h u b}, \alpha_{e x}^{h u b}, \alpha_{i n}^{t i p}, \alpha_{e x}^{t i p}-$ angles of the tip and hub endwalls at the inlet and exit (Fig. 10). 


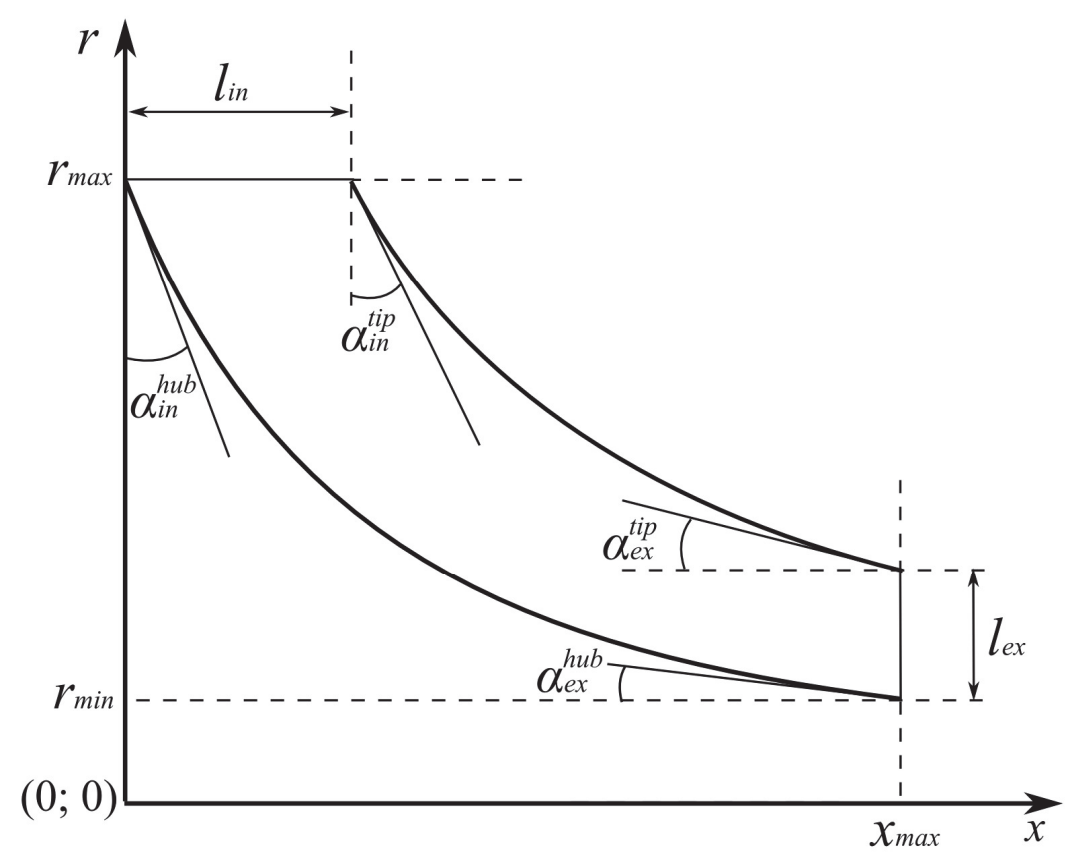

Fig. 10 - View of the rotor in the meridional plane

The blade is defined on two sections of rotational surfaces of the tip and hub endwalls. The sections are described by coordinates: $r \varphi$ - along the circumference; $s$ - distance from the leading edge. Profile coordinates on rotational surfaces of the tip and hub endwalls are found as a sum of coordinates for the mean line $r \varphi_{m l}$ (Fig. 11a) and profile thickness $\Delta r \varphi$ (Fig. 11b):

$$
r \varphi(s)=r \varphi_{m l}(s)+\Delta r \varphi(s)
$$

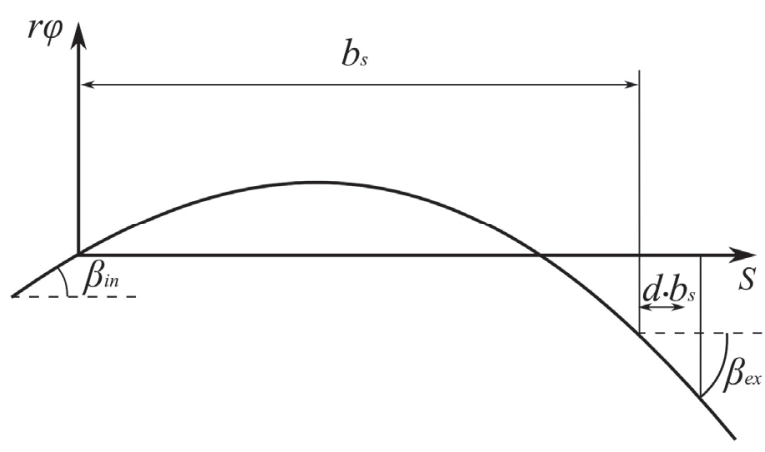

$a$

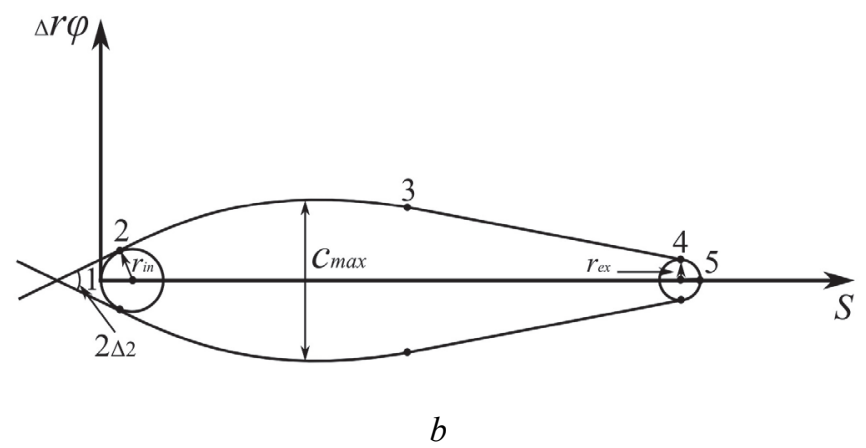

Fig. 11 - Blade section: $a$-blade mean line; $b$ - blade thickness with respect to the mean line 
The mean line is a 3-rd order polynomial (Fig. 11a):

$$
r \varphi_{m l}=\sum_{i=0}^{3} a_{i} s^{i}
$$

where $a_{i}$ - coefficients. The profile, symmetrical with respect to the mean line is composed of: 1-2 - leading edge; 2-3 - circle arc; 3-4 - straight interval; 4-5 - trailing edge.

The initial data for building the profile are: $b_{s}$ - profile width; $\beta_{i n}, \beta_{e x}$ - mean line angles at the leading and trailing edge; $r_{i n}, r_{e x}$ - leading/trailing edge radiuses; $c_{\max }-$ maximum profile thickness; $\Delta \alpha$ - leading edge angle; $d$-distance from the trailing edge, where the second derivative of the mean line equals 0 (Fig. 11).

\section{D flow calculation method}

For numerical investigations of flow, the software complex IPMFlow is used, which is the development of the software systems FlowER and FlowER-U. It implements the following elements of the mathematical model: the Reynolds-averaged nonstationary Navier-Stokes equations, SST differential two-parameter model of turbulence of Menter, implicit quasimonotone high-order ENO-scheme. To account for real thermodynamic properties of the working fluid the Tammann equation of state or the modified Bennedict-Webb-Rubin equation of state with 32 coefficients are used. The results of computations obtained from the code IPMFlow have the necessary reliability in the qualitative structure of flow and in the quantitative characteristics of the isolated turbine cascades and turbine as a whole $[15,16]$.

\section{Example of design of the flow part of a radial-axial ORC turbine}

The designed ORC turbine is a $100 \mathrm{~kW}$ machine operating on MDM as a working medium. The inlet/exit parameters were determined the same as for the $200 \mathrm{~kW}$ machine. The resulting pressure drop in the turbine blading system was also equal to 70 . The rotational speed of the rotor was assumed this time equal to $14000 \mathrm{rev} / \mathrm{min}$. Main geometric characteristics of the stator/rotor $(\mathrm{S}, \mathrm{R})$ configuration, including inlet/exit radiuses $(r)$, blade heights $(h)$ and blade numbers $(z)$ are given in Table 1 . The minimum blade height is here $5.43 \mathrm{~mm}$. The meridional section of the turbine stage and hub-to-tip rotor sections together with an isometric view of the blading system are presented in Figure 12.

Geometric characteristics of flow path for radial-axial turbine

Table 1.

\begin{tabular}{|c|c|c|c|c|c|c|c|c|c|}
\hline$r_{i n}, \mathrm{~S}$ & $r_{e x}, \mathrm{~S}$ & $l_{i n}, \mathrm{~S}$ & $l_{e x}, \mathrm{~S}$ & $z, \mathrm{~S}$ & $r_{i n}, \mathrm{R}$ & $r_{m i d . e x}, \mathrm{R}$ & $l_{i n}, \mathrm{R}$ & $l_{e x}, \mathrm{R}$ & $z, \mathrm{R}$ \\
\hline 232,96 & 199 & 5.43 & 5.43 & 57 & 185 & 85.105 & 5.43 & 70.19 & 11 \\
\hline
\end{tabular}

Although the flow system consists of only one stage which consumes a large pressure drop, flow pictures such as velocity vectors in meridional and blade-to-blade sections or static pressure contours look favourable, Figures 13-16. The maximum Mach number in the entire flow domain does not exceed 2. The flow patterns do not exhibit shock phenomena nor separations. As a result, the flow efficiency is high and equals $88.5 \%$. 


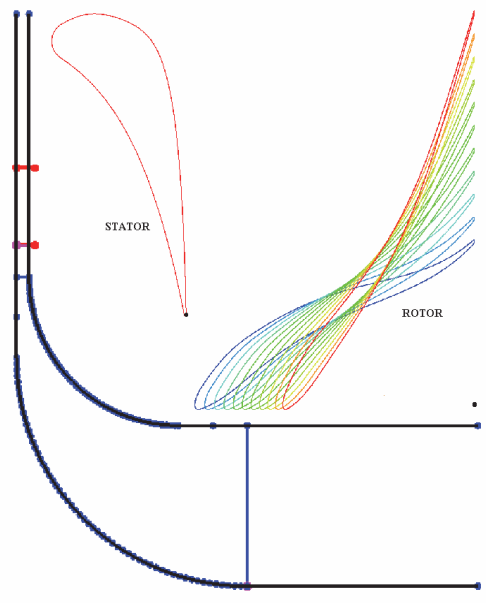

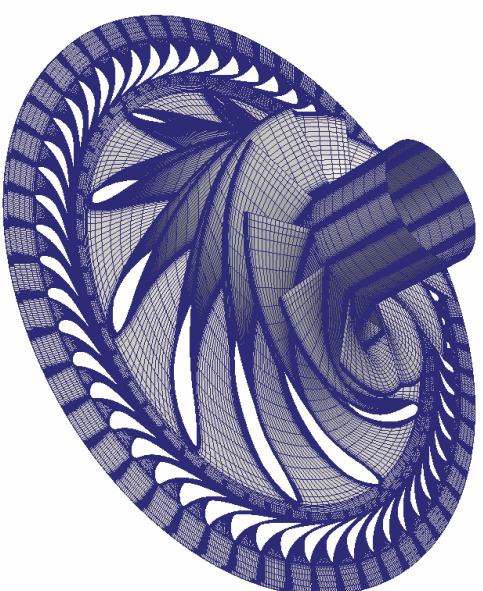

$b$

Fig. 12 - View of the flow system for the radial-axial turbine: $a$ - meridional section; $b$ - isometric view

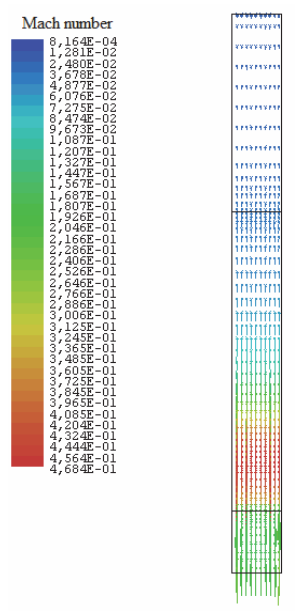

S

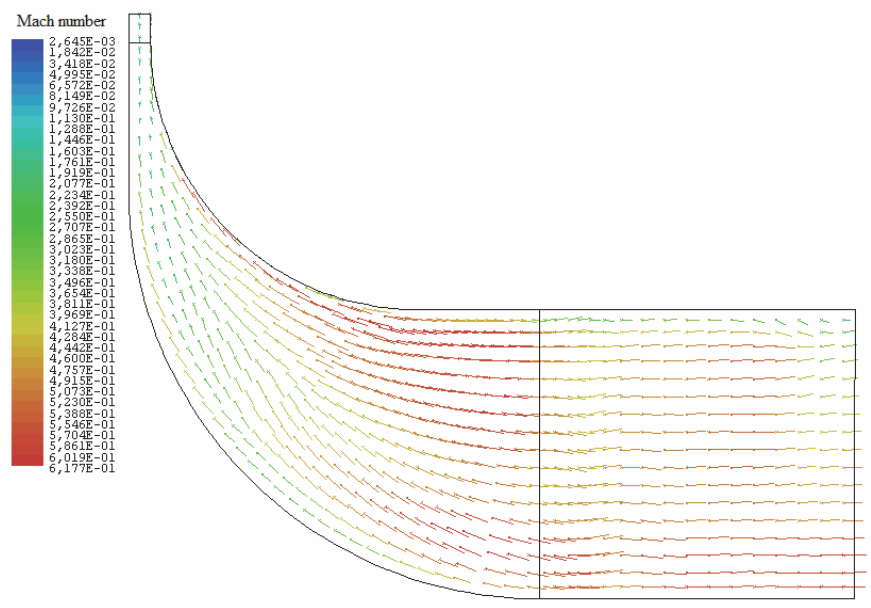

$\mathrm{R}$

Fig. 13 - Velocity vectors colored by Mach number at mid ade-to-blade section

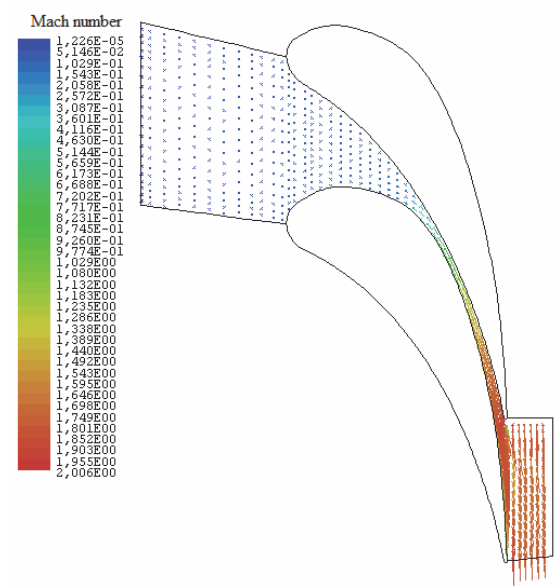

$\mathrm{S}$

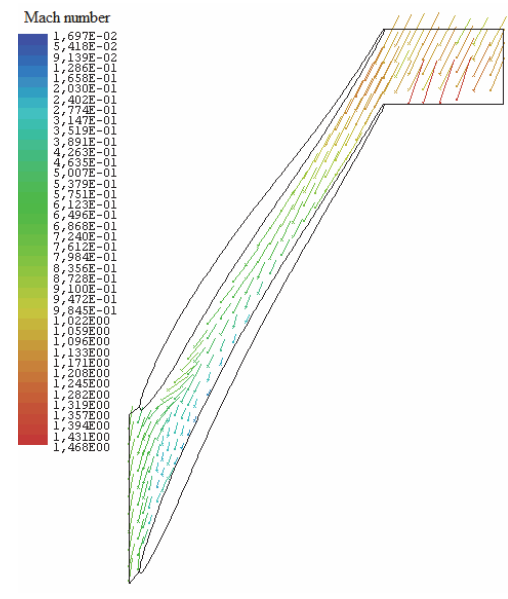

$\mathrm{R}$

Fig. 14 - Velocity vectors colored by Mach number at mid blade span 


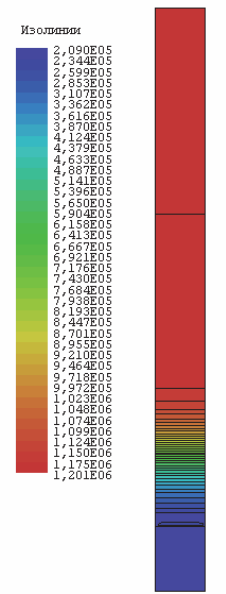

$\mathrm{S}$

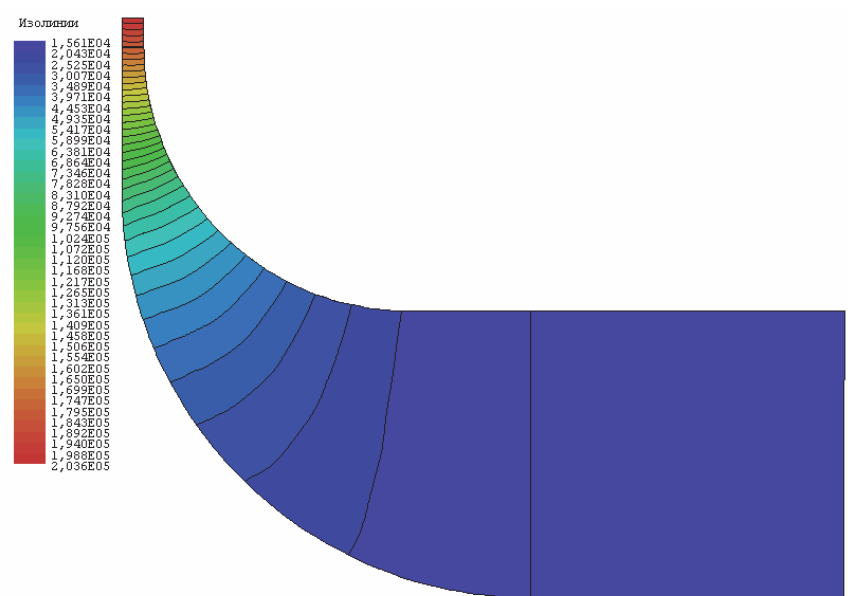

$\mathrm{R}$

Fig. 15 - Static pressure contours at mid blade-to-blade section

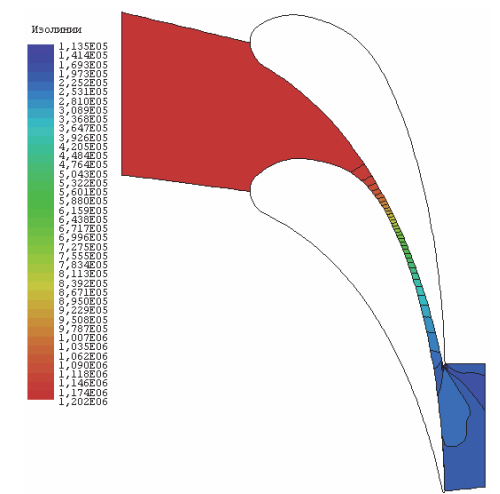

$\mathrm{S}$

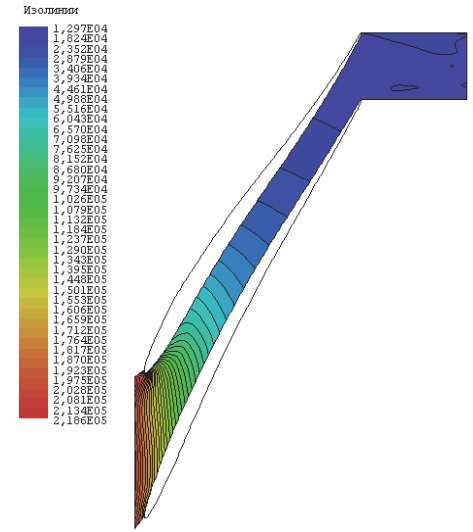

$\mathrm{R}$

Fig. 16 - Static pressure contours at mid blade span

\section{Conclusions}

The described design methods enable the elaboration of radial-axial turbines for ORC cogeneration units. The methods are based on mathematical models of various levels of complexity - from 1D to 3D. 3D turbulent flow model is realised in the software complex IPMFlow or in software complex ANSYS. Two variants of the flow path of radial-axial turbines were presented. All turbine variants exhibit satisfactory flow efficiencies.

Literature: 1. Casci, C. Modern Research Topics in Aerospace Propulsion [Text] / C. Casci, G. Angelino, L. De Luca, W. A. Sirignano. - New York : Springer-Verlag, 1991. - 375 p. - ISBN-13: 9780387974170. 2. Harinck, $J$. Three-Dimensional RANS Simulation of a High-Speed Organic Rankine Cycle Turbine [Electronic resource] / J. Harinck, D. Pasquale, R. Pecnik, P. Colonna // First Int. Semin. ORC Power Syst. ORC. Delft. - 2011. - Available from: http://orc2011.fyper.com/uploads/File/ORC\%20BoA.pdf. - 01.02.2015.

3. Traupel, $W$. Thermische Turbomaschinen [Text] / W. Traupel. - Springer Singapore Pte. Limited, 2001. 4. Абрамов, В. И. Тепловой расчет турбин [Текст] / В. И. Абрамов, Г. А. Филиппов, В. В. Фролов. - М. : Машиностроение, 1974. - 183 с. 5. Zucrow, M. J. Gas Dynamics Volume I and II [Text] / M. J. Zucrow, J. D. Hoffman. - John Wiley \& Sons, 1976. - 772 p. 6. Guardone, A. Influence of Molecular Complexity on Nozzle Design for an Organic Vapor Wind Tunnel [Text] / A. Guardone, A. Spinelli, V. Dossena, V. Vandecauter // First Int. Semin. ORC Power Syst. ORC. $-2011 .-6$ p. 7. Sauer, R. General characteristics of the flow through nozzles at near critical speeds [Text] / R. Sauer. - Washington : National Advisory Committee for Aeronautics. - 1947. - 20 p. 8. ANSYS Products CFX, Release 12. - Available from: http://www.ansys.com. - 10.03.2014. 9. Бойко, А. В. Основы теории оптимального проектирования проточной части осевых турбомашин [Текст] / А. В. Бойко, Ю.Н.Говорущенко. - Харьков : Вища школа, 1989. - 217 с. 
10. Билан, А. В. Автоматизированное проектирование лопаток паровых турбин [Текст] / А. В. Билан, В. Н. Билан // Компрессорное и энергетическое машиностроение. - 2006. - № 3(5). - С. 66-68. 11. Lampart, $P$. Direct Constrained Comptational Fluid Dynamics Based Optimization of Three-Dimensional Blading for the Exit Stage of a Large Power Steam Turbine [Text] / P. Lampart, S. Yershov // Transactions of the ASME. Journal Engineering for Gas Turbines and Power. - 2003. - Vol. 125, No 1. - P. 385-390. 12. David, E. Goldberg. Genetic Algorithms in Search, Optimization, and Machine Learning [Text] / David E. Goldberg. - Addison-Wesley Professional, 1989. - 432 p. - ISBN-10: 0201157675, ISBN-13: 9780201157673. 13. Thevenin, D. Optimization and Computational Fluid Dynamics [Text] / D. Thevenin, G. Janiga. - Springer-Verlag, 2008. - 293 p. - ISBN 978-3-540-72152-9. 14. Русанов, А. В. Использование современных компьютерных технологий для создания высокоэффективных проточных частей радиально-осевого типа [Текст] / А. В. Русанов // Компрессорное и энергетическое машиностроение. 2013. - № 2(32). - C. 4-9. 15. Lampart, P. Validation of turbomachinery flow solver on turbomachinery test cases [Text] / P. Lampart, S. Yershov, A. Rusanov // International conference SYMKOM'02: Compressor \& turbine stage flow path theory, experiment \& user verification, Cieplne Maszyny Przeplywowe. Turbomachinery. - 2002. - Poland : Politechnika Lodzka, Lodz. - Vol. 122. - P. 63-70. 16. Хомылев, С. A. Численное исследование обтекания турбинных решеток профилей: часть 1 - верификация расчетного метода [Текст] / С. А. Хомылев, С. Б. Резник, С. В. Ершов // Энергетические и теплотехнические процессы и оборудование. Вестник НТУ «ХПИ» : сб. науч. трудов. - 2008. - № 6. - С. $23-31$.

Bibliography (transliterated): 1. Casci, C. et al. Modern Research Topics in Aerospace Propulsion. New York : Springer-Verlag, 1991. ISBN-13: 9780387974170. Print. 2. Harinck, J. et al. "Three-Dimensional RANS Simulation of a High-Speed Organic Rankine Cycle Turbine." First Int. Semin. ORC Power Syst. ORC. Delft., 2011. Web 01 February $2015<$ http://orc2011.fyper.com/uploads/File/ORC\%20BoA.pdf>. 3. Traupel, W. Thermische Turbomaschinen. Springer Singapore Pte. Limited, 2001. Print. 4. Abramov, W. I., G. A. Filipov and W. W. Frolov. Tieplowoj rascziot turbin. Moscow: Mashinostroenie, 1974. Print. 5. Zucrow, M. J., and J. D. Hoffman. Gas Dynamics Volume I and II. John Wiley \& Sons, 1976. Print. 6. Guardone, A. et al. "Influence of Molecular Complexity on Nozzle Design for an Organic Vapor Wind Tunnel." First Int. Semin. ORC Power Syst. ORC. 2011. Print. 7. Sauer, R. General characteristics of the flow through nozzles at near critical speeds. Washington : National Advisory Committee for Aeronautics, 1947. Print. 8. ANSYS Products CFX, Release 12. Web. 10 March $2014<\mathrm{http}$ //www.ansys.com>. 9. Boiko, A. V., and Yu. N. Govorushchenko. Osnovi teorij optimalnogo proektirovanijya protochnoj chasti osevich turbomashin. Kharkov : Vishcha shkola, 1989. Print. 10. Bilan, A. V., and V. N. Bilan. "Avtomatizirovanoe proektirovanie lopatok parovih turbin." Kompresornoe I energeticheskoe mashinostroenie. Sumi, 2006. Print. 11. Lampart, P., and S. Yershov. "Direct Constrained Comptational Fluid Dynamics Based Optimization of Three-Dimensional Blading for the Exit Stage of a Large Power Steam Turbine." Transactions of the ASME, Journal Engineering for Gas Turbines and Power 125.1 (2003): 385-390. Print. 12. David, E. Goldberg. Genetic Algorithms in Search, Optimization, and Machine Learning. Addison-Wesley Professional, 1989. Print. 13. Thevenin, D., and G. Janiga. Optimization and Computational Fluid Dynamics. Berlin: Springer-Verlag, 2008. Print. 14. Rusanov, A.V. "Ispolzovanie sovremenih komputernih tehnologij dlya sozdaniya visokoefektivnih protochnih chastej radialno-osevogo tipa." Kompresornoe I energeticheskoe mashinostroenie 2(32) (2013): 4-9. Print. 15. Lampart, P., S. Yershov and A. Rusanov. Validation of turbomachinery flow solver on turbomachinery test cases. No 122. Poland : Politechnika Lodzka, 2002. 63-70. Print. 16. Homilev, S. A., S. B. Reznik and S. V. Ershov. "Chislenoe issledovanie obtekaniya turbinih reshotok profilej: chast 1 - verifikaciya raschetnogo metoda." Visnyk NTU "KhPI". Serija: Energetychni ta teplotehnichni procesy j ustatkuvannja. No 6. Kharkov : NTU "KhPI", 2008. 23-31. Print.

Received to editorial board 16.02.15 